$\mathrm{Oz}$

Volume 3

Article 7

$1-1-1981$

\title{
A Museum Addition for a University: an entry in the James Harrison Steedman Competition
}

Thomas Lance Braht

Follow this and additional works at: https://newprairiepress.org/oz

Part of the Architecture Commons

(c) (i) $(9)$

This work is licensed under a Creative Commons Attribution-Noncommercial-No Derivative Works 4.0 License.

\section{Recommended Citation}

Braht, Thomas Lance (1981) "A Museum Addition for a University: an entry in the James Harrison Steedman Competition," Oz: Vol. 3. https://doi.org/10.4148/2378-5853.1022

This Article is brought to you for free and open access by New Prairie Press. It has been accepted for inclusion in Oz by an authorized administrator of New Prairie Press. For more information, please contact cads@k-state.edu. 


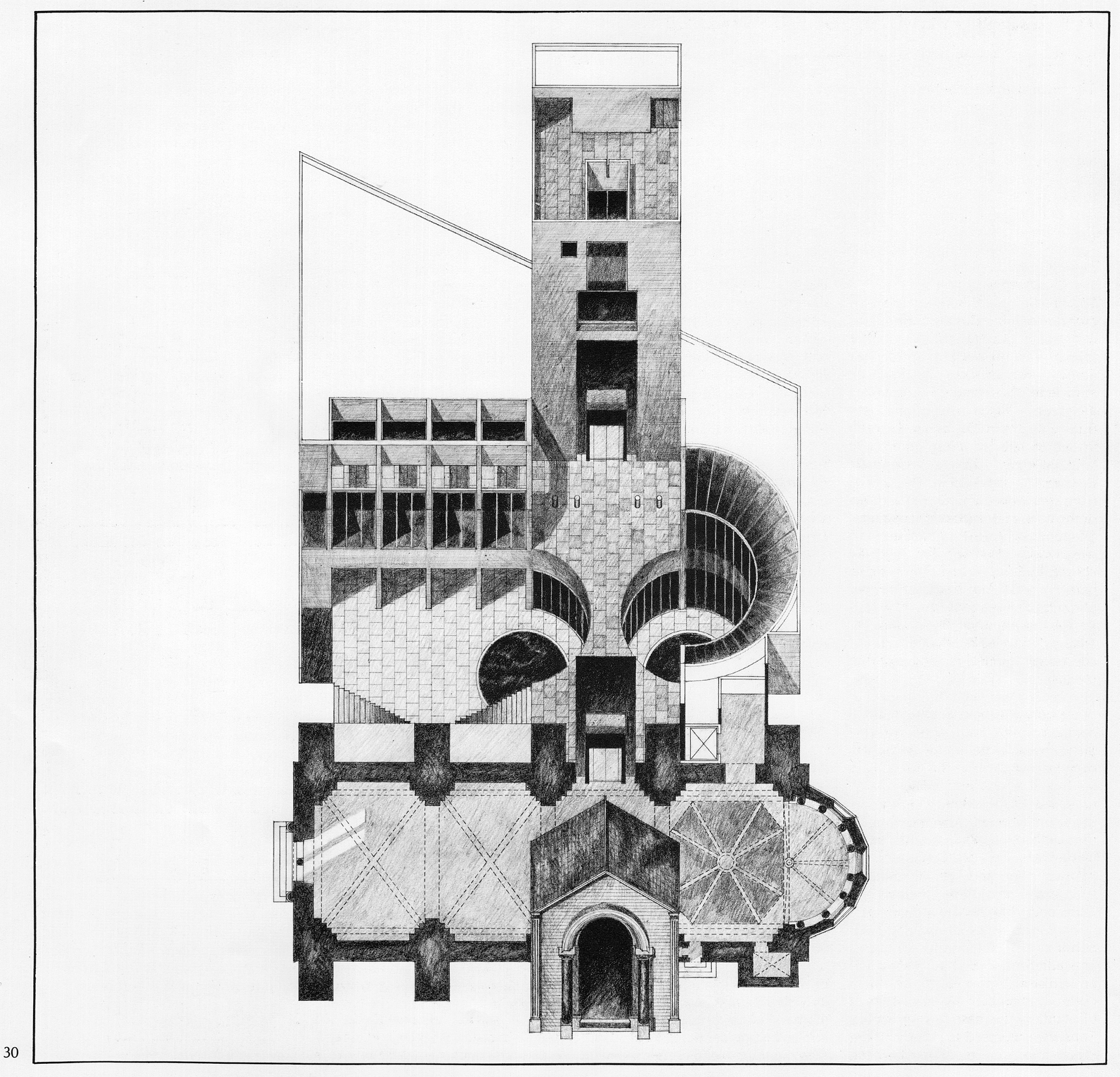


A Museum Addition for a University

an entry in the James Harrison Steedman Competition

Thomas Lance Braht

\section{Design Situation}

During the 1880's in a midwestern city a small church was built at the edge of a college campus. This church was faithfully built in the French Romanesque manner by knowledgeable and well-traveled architects. Since that time the original French order of monks were forced to sell off their once large land holdings due to economic pressures. After World War II the state bought the church site as part of the university expansion program. The university feels that the most useful dedication for the fine old church building is to have it made part of a small but elegant museum compound. Their proposed program for this new facility calls for approximately 8 or 9,000 square feet of additional exhibition and support spaces

The empty church now sits on a one acre grassy site. It is bounded to the north by a three story greystone agronomy building and a gravel path leading to a footbridge. This bridge crosses a creek ravine which forms the eastern boundary of the site. To the south lies a small tree preserve owned by the State College of Forestry. To the west, across the road, are large old fraternity houses, clubs and a few faculty residences.

\section{Solution}

The addition of a new structure to any historical building of such definite character is always very difficult. In this case further restrictions were imposed under Historical Preservation rulings stating that the existing building may be added to, altered or surrounded only in ways that are intended to preserve the details, the form and the essential character of the building as it now stands. Additionally they suggest to architects who may work on the building that the roof line, the unfinished tower, the apse, both its interior and its exterior, the south porch and the west entrance, remain untouched. Where doors or passageways are required at floor level, these may be cut with care through the walls between the buttresses.

The new addition attempts to address some of the major problems inherent to this project concerning site, scale, character, organization and connection. This solution also stems from a strong desire to coincide with the university's concern of maintaining the integrity of the church; partly through the continued maintenance and reinforcement of the complimentary grassy plane upon which the old church stands. The building is conceived as the central element in a larger scheme, or "building compound," surrounded by a serene pastoral lawn. It is here that the first difficulty arose. A building "complex" or "compound" atmosphere immediately suggested a series of smaller independent structures, however, this is impractical for several reasons. First, the site was already rather constraining, particularly after considering the huge scale of the church and a desire not to obliterate important features of the building. Secondly, the building program suggested a rather consolidated structure, due both to minimal total square footage and specific functional considerations. The solution thus took on a rather compact plan configuration. Within the scheme are readily identifiable elements or objects which considered separately have rather distinct characteristics, yet together form a strong organizational whole.

Perhaps most evident among these elements is the "campanile" or large vertical tower which appropriately enough contains the primary vertical circulation, secondary/theater entrance, information desk, administrative offices, library, and observation deck. This tower also serves specific functions at different scales. On the largest scale of the street, the tower fills in the gap between the agronomy building and the church to provide a more evenly defined textural "wall" along the street corridor. At the scale of the site, the tower provides a needed additional element to the northern side of the lot. To the east the apse and creek provide a definite sense of place. To the south this is accomplished by the beautiful side entrance porch, the bordering stone wall and the small tree preserve; and to the west by the street and the imposing front facade of the church. The tower in a sense balances the composition, and at the scale of the building compliments the predominantly vertical nature of the church. This is further enhanced by the sunken cloistered area between both structures. The tower also terminates
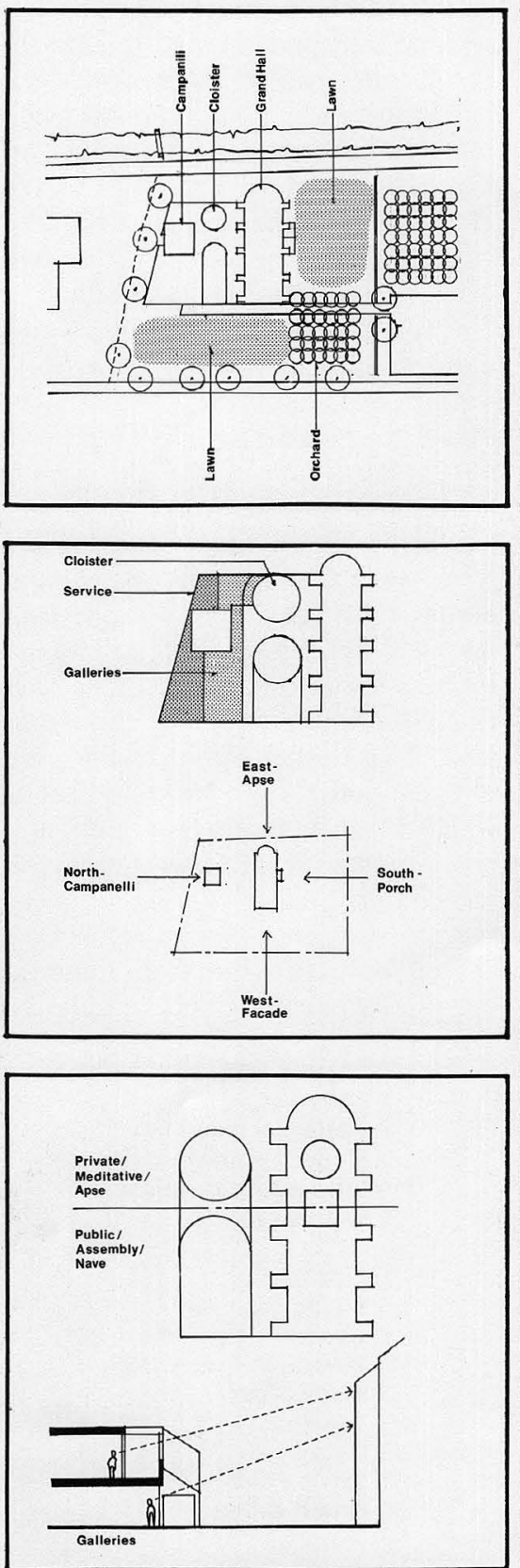
a strong axial progression running parallel to the street and perpendicular to the church nave. This "transcept" axis firmly links itself with the existing southern porch and along with the sunken stair connection and similar window fenestration in both the tower and the north wall of the church, helps to reinforce the apse and nave spaces.

The axial connection performs another important organizational role. The stair connection inside the church essentially serves the same architectural purpose as a choir screen, dividing one large interior space into two distinct ones, the easily accessible public nave, and the more sacred apsidal area. This distinction is carried through to the exterior where the sunken cloistered courtyard becomes divided into two exterior rooms; the larger public courtyard and the smaller, more intimate sculpture courtyard accessible only from the interior. The plan of these courtyard spaces echoes the basic plan shape of the old church itself. These outdoor rooms also help move the new building mass away from the church. As mentioned earlier, this provides a more balanced composition and creates a more sensitive material juxtaposition, particularly along the front wall. This wall is intentionally very plain and reticent, a good portion of which is only three feet high and never makes direct contact with the old church.

Directly off the cloistered areas lie the more serene, contemplative

1 Galleries

2 Sculpture courtyard

3 Storage/workshop

4 Information/bookstore

5 Seminar rooms

6 Offices

7 Cloister

8 Public courtyard

9 Library/mezzanine

10 Theater entrance

11 Restrooms

12 Theater

13 Open

14 Service dock

15 Grand galler
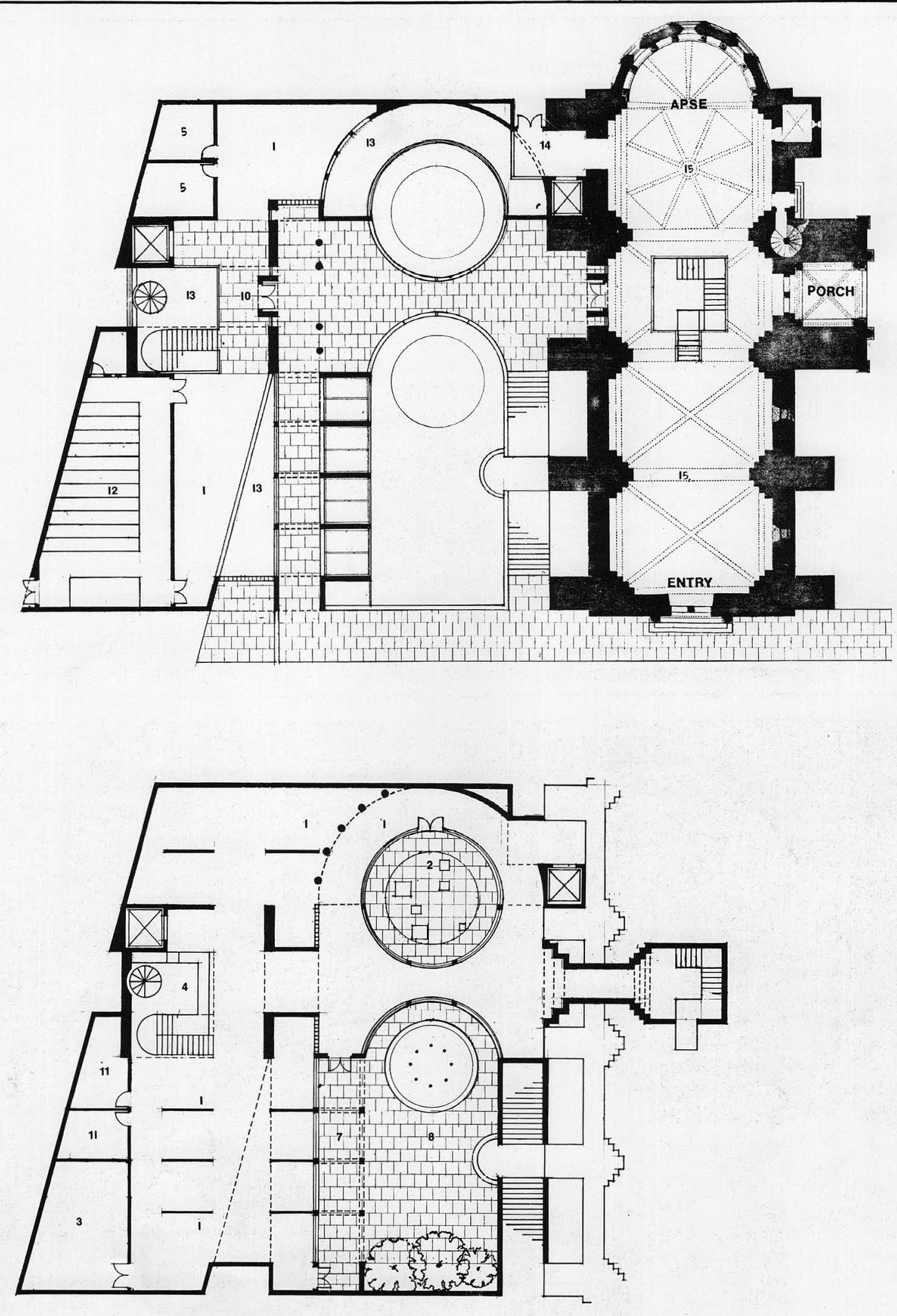

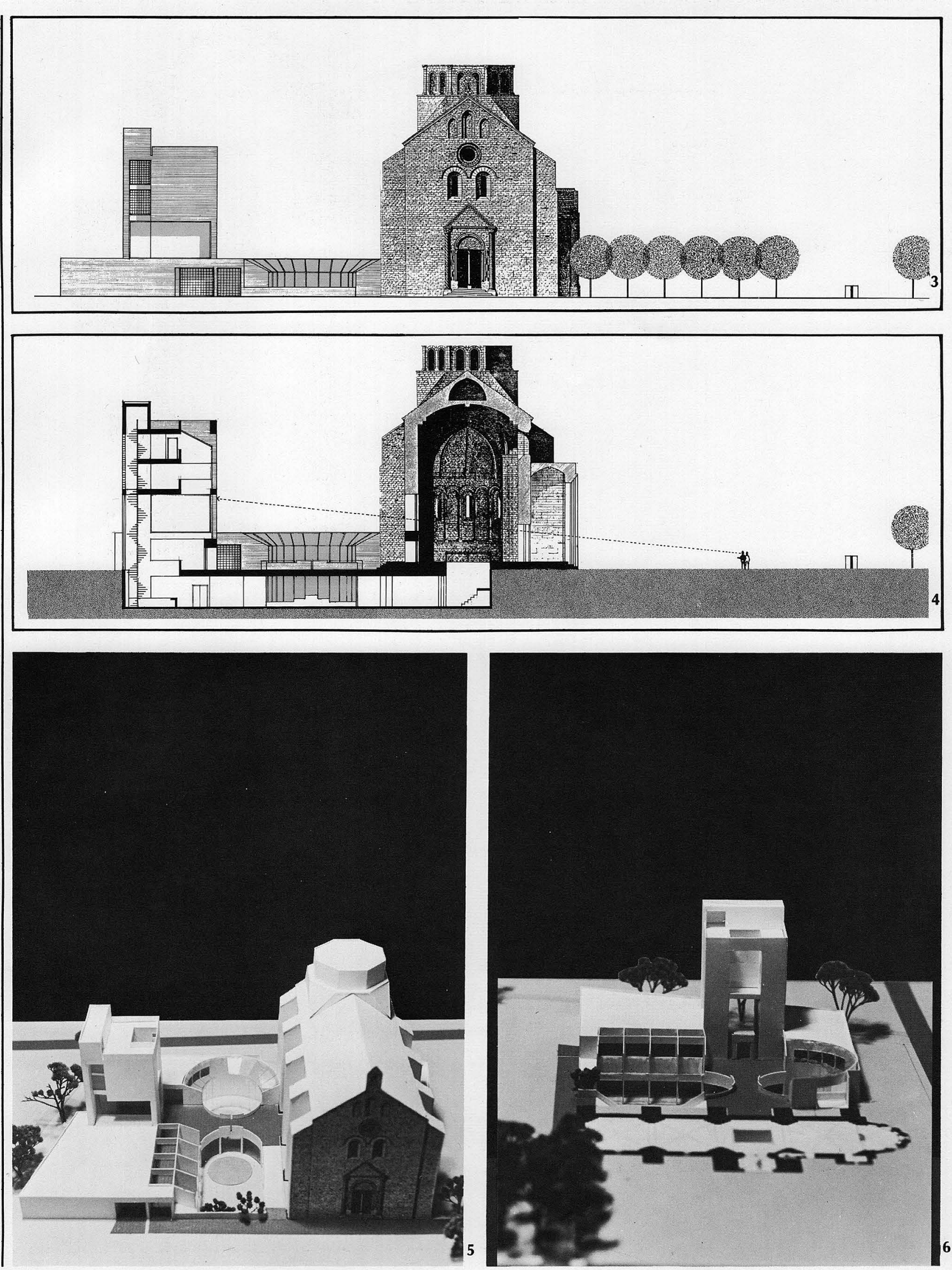

gallery spaces. Since all the galleries face in towards the open courtyards, direct visual connection to the church is always possible, regardless of which gallery one is in. Gallery spaces have been designed with the intention of being capable of accommodating fluctuating displays.

With the fragmentation of the scheme into easily definable parts, some desirable functional considerations result. Both the new addition and the old church may operate together or independently. Presumably, the church would be left open at all times. Within the new structure the tower and roof deck may be completely closed off. Each gallery floor may also operate independently or together. This would be particularly advantageous on the first floor theater level for evening events. With all the vertical circulation adjacent to, or in easy visual inspection of the main information desk, maximum security standards may be maintained with a minimal staff. In fact, during slow periods of operation one person could easily supervise the entire complex.

\section{The Competition}

The James Harrison Steedman Traveling Fellowship in Architecture is an annual design competition jointly sponsored by Washington University and the American Academy in Rome. The winner receives one year of residency at the American Academy in Rome and a stipend totaling nine thousand dollars. This scheme received the award of "First Alternate," or second place in the competition.

1 Level one
2 Lower level
3 West elevation
4 Section through campanile
5 View looking east
6 View looking north

